\title{
HISZPANIA JAKO MIEJSCE SCHRONIENIA OPOZYCJI \\ W OKRESIE PIERWSZEJ WOJNY \\ DOMOWEJ I DYKTATURY LUCJUSZA \\ KORNELIUSZA SULLI (88-79 P.N.E.)
}

Tomasz Ładoń*

\begin{abstract}
During the First Civil War and the dictatorship of Lucius Cornelius Sulla, Spain was one of the main directions of political emigration. The author of the article distinguished three stages. The first occurred immediately after the outbreak of the First Civil War in 88 BC. A small group of refugees escaped from the repression of Sullan to Spain. The second stage involved the escape from the Marian repression that broke out in Rome after Sulla's departure to the war with the Mithridates. The third stage of emigration to Spain followed the victory of Lucius Cornelius Sulla in the First Civil War in Italy and the introduction of proscription (82 BC). The Iberian Peninsula for the defeated Marians became not only the main direction of escape from repression, but also a center of opposition to the rulers of Rome.
\end{abstract}

Keywords: Sertorius, Sulla, Crassus, emigration, Spain.

Słowa kluczowe: Sertoriusz, Sulla, Krassus, emigracja, Hiszpania.

* Akademia im. Jana Długosza w Częstochowie, Instytut Historii, al. Armii Krajowej 36a, 42-200 Częstochowa, tladon@wp.pl. 
Pierwsza wojna domowa nie tylko spolaryzowała scenę polityczną w Republice, lecz także doprowadziła do stanu, w którym przemoc była wykorzystywana w państwie na niespotykaną dotąd skalę 1 . Zarówno Lucjusz Korneliusz Sulla, jak i Gajusz Mariusz - czyli główni oponenci we wspomnianym konflikcie - stosowali wobec wrogów krwawe represje ${ }^{2}$. Polityczni przeciwnicy byli wyjmowani spod prawa, ich majątki konfiskowane, a każdego ogłoszonego wrogiem publicznym (hostis publici) można było bezkarnie zabić (Appel, 2013: 150-162). W obawie o własne życie czołowi obywatele, których nazwiska znajdowały się na różnego rodzaju listach proskrypcyjnych, często opuszczali Rzym i Italię, szukając schronienia w różnych częściach imperium.

Prowincje hiszpańskie nie były - przynajmniej w latach osiemdziesiątych I wieku - głównym kierunkiem, wybieranym przez uciekinierów z Italii. Wynikało to przede wszystkim z faktu, że w okresie pierwszej wojny domowej największy procent zbiegów stanowili przeciwnicy rządzących wówczas Rzymem Mariusza i Cynny. Uciekinierzy - co oczywiste - kierowali więc swe kroki do Sulli, prowadzącego wówczas wojnę z Mitrydatesem VI Eupatorem na Wschodzie ${ }^{3}$. Innym ewentualnym kierunkiem ucieczki była Afryka, gdzie z kolei przebywał nieprzychylny mariańczykom Kwintus Cecyliusz Metellus Pius ${ }^{4}$. Hiszpanię jako teren o silnych wpływach mariańskich raczej pomijano jako miejsce

$1 \mathrm{Na}$ temat przemocy w rzymskim życiu publicznym w okresie schyłkowej Republiki zob. między innymi Heaton, 1939; Lintott, 1968; Sherwin-White, 1956: 1-9; Schuller, 1974/1974: 140-153; Gruen, 1974: 405-448; Smith, 1977: 150-174; Rouland, 1979: 32-41; Kowalski, 1983/1984: 75-92; 2007: 103-114; Labruna, 1991: 119-137. Wszystkie daty w tekście artykułu dotyczą czasów przed narodzeniem Chrystusa.

2 Największe nasilenie miały one w latach $88-87$ i $82-81$. Zob. Broughton, 1952: 40-42, 46, 69 (tam wskazówki źródłowe).

3 Sulla wyjechał na wojnę z Mitrydatesem w 88 roku (Broughton, 1952: 40). Uciekinierów z Italii, którzy dołączyli do niego na Wschodzie próbuje identyfikować Keaveney (1984: 114-150).

4 Liv., Per. 84; Plut., Crass. 6.2. Por. App., BC 1.80.365; Ooteghem, 1967: 180-181. 
schronienia. Dopiero po zwycięstwie Sulli w tak zwanej wojnie sullańskiej toczonej w Italii w latach 83-82, uciekający z Rzymu mariańczycy kierowali swe kroki do Hiszpanii, gdzie od początku 82 roku zarząd nad obydwiema tamtejszymi prowincjami sprawował jeden z przywódców mariańskich, Kwintus Sertoriusz ${ }^{5}$. Początkowo renegaci mariańscy szukali na Półwyspie Iberyjskim azylu politycznego, ale $\mathrm{z}$ biegiem czasu, gdy ich liczba znacznie wzrosła, spróbowali zorganizować ośrodek oporu wobec władzy sullańczyków w Rzymie.

Materiał źródłowy, dzięki któremu można uzyskać informacje na temat zbiegów z Rzymu, szukających schronienia w prowincjach hiszpańskich, jest bardzo skromny. Do dyspozycji pozostają przy tym jedynie źródła literackie, często fragmentaryczne i ogólnikowe. Wynika to między innymi z faktu, że autorzy antyczni koncentrowali swą uwagę na działaniach najważniejszych osób w państwie. Szczegółowo opisali więc na przykład ucieczkę wyjętego spod prawa Mariusza do Afryki ${ }^{6}$, zaś o jedenastu represjonowanych przez Sullę wraz z nim czołowych mariańczykach, zbiegłych na Półwysep Iberyjski, wspomnieli tylko na marginesie prowadzonych rozważań7. Jedynie w przypadku, gdy do Hiszpanii, w poszukiwaniu azylu, przedostawała się osoba pokroju Marka Licyniusza Krassusa, można znaleźć w źródłach bardziej szczegółową relację (Plut., Crass. 4.1-6.1). Dodatkowym utrudnieniem w prowadzonych tu badaniach jest w ogóle słaba baza źródłowa do rekonstruowania dziejów rzymskiej Hiszpanii dla pierwszych dwóch dekad I wieku (Richardson, 2004: 156) ${ }^{8}$. Wzrost liczby źródeł można odnotować dopiero wówczas, gdy wokół Sertoriusza

5 Plut., Sert. 6.1-2; Iul. Exuper. 8. García Mora, 1991: 321-382, zwłaszcza 374; Rijkhoek, 1992: 178-187; Konrad, 1994: 85-87; Ładoń, 2011: 40-44.

6 Zob. Plut., Mar. 40, a także: Cic., p. red. in sen. 20, Pis. 43; Diod. 37.29.3; Vell. 2.19.4; Val. Max. 6.9.6; Sen., Contr. 1.1.5, 7.2.6; Luc. 2.9193, 8.269; App., BC 1.62.279-280; Exsuper. 21; Oros. 5.19.8. Zob.: Carney, 1961: 98-121; Ooteghem, 1963: 288-302; Letzner, 2000: 143; Labitzke, 2009: 213.

7 Gran. Lic. 35.10 Cr. Por. App., BC 1.60.271.

8 Por. Schulten, 1937: 149-159. 
w latach siedemdziesiątych na Półwyspie Iberyjskim ukształtuje się główny ośrodek oporu wobec rządów sullańczyków w Republice (Schulten, 1937: 160-249; Ładoń, 2011: 9-16).

Nie dziwi zatem, że w literaturze przedmiotu kwestia przymusowej emigracji politycznej spowodowanej strachem przed represjami była podejmowana tylko ogólnie, w odniesieniu na przykład do całych dziejów Republiki ${ }^{9}$. Jeśli chodzi o Hiszpanię, szczegółowych badań w tym kontekście nie prowadzono, zwłaszcza dla tak krótkiego periodu, jakim jest pierwsza wojna domowa i dyktatura sullańska ${ }^{10}$.

W okresie pierwszej wojny domowej pierwsi emigranci polityczni opuścili Rzym już w 88 roku, gdy Sulla, po zwycięstwie odniesionym w rywalizacji z Publiuszem Sulpicjuszem Rufusem i Gajuszem Mariuszem, przystąpił do zdecydowanej rozprawy z wrogami, w wyniku czego dwunastu najzacieklejszych spośród nich (na czele z Mariuszem i jego synem) na polecenie zwycięzcy ogłoszono wrogami publicznymi ${ }^{11}$. Nie ścigano ich jednak chyba z wielką zaciekłością, gdyż jedynie Sulpicjusz Rufus nie uniknął śmierci ${ }^{12}$, a pozostałej jedenastce udało się zbiec z Italii. Mariusz po pełnej brawurowych przygód ucieczce samotnie przedostał się do Afryki ${ }^{13}$, zaś Brutus i przynajmniej niektórzy z jego towarzyszy dotarli do Hiszpanii.

Wybór prowincji hiszpańskich jako miejsca schronienia dla zwolenników Mariusza nie dziwi, jak bowiem już wspominałem, sześciokrotny konsul cieszył się tam dużą popularnością. Wiązała się ona oczywiście z pobytem Mariusza na Półwyspie Pirenejskim w trakcie sprawowania przez niego namiestnictwa w Hiszpanii

9 Zob.: Wilson, 1966; Kelly, 2006.

10 W szerszym wymiarze dla I wieku zob. Wilson, 1966: 29-42.

11 [Cic.] Rhet. Herenn. 1.25, 4.31; Cic., Cat. 3.24; Orat. 3.8, 3.11; Brut. 168, 307; Nep., Att. 2.1-2; Liv., Per. 77; Vell 2.19.1; Val. Max. 3.8.5, 6.5.7; Plut., Sull. 10.1-5; Flor. 2.9.8; App., BC 1.60.271; Ampel. 42.1; Exsuper. 20; Oros. 5.19.6. Szerzej: Letzner, 2000: 142-144; Lovano, 2002: 22, przyp. 30; Appel, 2013: 151-159.

12 Liv., Per. 77; Val. Max. 6.5.7.

13 Zob. przyp. 7. 
Dalszej w latach 114-11314. W źródłach spośród uciekinierów do Hiszpanii imiennie wymieniony jest jedynie Marek Juniusz Brutus, pretor z 88 roku, który sprzeciwił się wówczas marszowi Sulli na Rzym ${ }^{15}$. Wiadomo, że Brutus nie uciekł na Półwysep Iberyjski sam ${ }^{16}$, ale ilu z pozostałych hostes przedostało się tam u jego boku, nie sposób stwierdzić. Być może uciekinierzy podzielili się na dwie grupy - pierwsza, w skład której weszli między innymi Publiusz Cetegus, jeden z braci Graniuszy, Publiusz Albinowanus, Letoriusz i Mariusz Młodszy, skierowała swe kroki do Hiempsala, władcy Numidów ${ }^{17}$, pozostali zaś towarzyszyli Brutusowi w drodze do Hiszpanii, prawdopodobnie Hiszpanii Dalszej, prowincji, której zarząd niegdyś sprawował sławny Decymus Juniusz Brutus Kallaikus i który na pewno związał ze swoim rodem tamtejsze elity, dzięki czemu zbiedzy z Italii mogli tam znaleźć przychylne i bezpieczne przyjęcie ${ }^{18}$. Na temat pobytu Brutusa (et consortes) w Hiszpanii nie zachowały się żadne szczegółowe informacje, wiadomo jedynie, że przebywali tam bardzo krótko i po wyjeździe Sulli na wojnę z Mitrydatesem powrócili do Rzymu (Gran. Lic. 35.7 Cr.).

Porządek, który Sulla ustanowił w państwie po marszu na Rzym, został obalony zaraz po tym, jak prokonsul opuścił Italię i udał się na Wschód. Tym razem w stolicy doszło do znacznie bardziej krwawych i zakrojonych na większą skalę represji, niż te mające miejsce kilka miesięcy wcześniej ${ }^{19}$. W obawie przed

14 Plut., Mar. 6.1. Por. Cic., Verr. 2.3.209. Zob. Jashemski, 1950: 125; Ooteghem, 1964: 89-91; Labitzke 2009: 40-42.

15 Plut., Sull. 9.2. O nim Münzer, 1918: 972.

16 Gran. Lic. 35.7 Cr: "ex Hispania Brutus ceter[ique] exules ad eum con[flu]xerunt”. Zob. Gabba, 1976: 109.

17 App., BC 1.62.280; Gabba, 1958: 178.

18 Liv., Per. 56; App., Ib. 72-73; por. Val. Max. 6.4.ext.1. Broughton, 1951: 487; Richardson, 2000: 162-163.

19 Vell. 2.22.1-4; Plut., Mar. 43-45; Sert. 5.1-5; App., BC 1.71-75; Flor. 2.9.13-17. Zob. Broughton 1952: 46 o dalszych wskazówkach źródłowych i Lovano (2002: 45-50), gdzie znajduje się dyskusja o tak zwanej „masakrze mariańskiej”; tam też dalsza literatura. 
śmiercią wielu zwolenników Sulli uciekło do niego bądź rozpierzchło się po różnych częściach imperium. Schronienia w Hiszpanii szukało jednak niewielu, a wśród nich - Marek Licyniusz Krassus.

Epizod o pobycie Krassusa na Półwyspie Iberyjskim po ucieczce z Italii został dość szeroko opisany przez Plutarcha $\mathrm{z}$ Cheronei. Warto go w tym miejscu przypomnieć. Biograf podaje oto, że wśród ofiar Mariusza i Cynny znaleźli się ojciec i starszy brat Krassusa, sam Krassus zaś został początkowo oszczędzony przez mariańczyków z powodu młodego wieku. W obawie o życie zdecydował się jednak opuścić Rzym w towarzystwie trzech przyjaciół i dziesięciu niewolników i czym prędzej udał się do Hiszpanii. Niegdyś odwiedził już tę prowincję, gdy jego ojciec był tam pretorem, i dzięki temu miał tam przyjaciół, gotowych udzielić mu schronienia. Gdy przybył na Półwysep, okazało się jednak, że wszyscy w Hiszpanii drżeli ze strachu przed Mariuszem, Krassus musiał więc pozostać w ukryciu. Azyl znalazł w jaskini, znajdującej się w granicach majątku niejakiego Wibiusza Pakcjanusa. Ten, choć podobno z radością przyjął uciekinierów, nie spotkał się z nimi osobiście, lecz zorganizował im dostawy jedzenia, a nawet zapewnił zbiegom towarzystwo niewolnic. To właśnie jedna z tych oswobodzonych już zapewne kobiet, będąc u schyłku życia, opowiedziała historię o hiszpańskich przygodach młodego Krassusa historykowi Fenestelli ${ }^{20}$, który zamieścił ją w swoim dziele i w ten sposób relacja trafiła do dzieła Plutarcha. Krassus pozostawał w ukryciu przez osiem miesięcy, a ujawnił się po śmierci Cynny. Dołączyło wówczas do niego sporo ludzi i z naprędce zebraną w ten sposób niewielką dwuipółtysięczną armią Krassus zaczął plądrować okoliczne miasta, w tym Malakę. Następnie na okrętach przedostał się do Afryki, do Metellusa, ale pokłócił się z nim wkrótce i powędrował prosto do Sulli. Na tej informacji Plutarch kończy opis pobytu Krassusa w Hiszpanii (Plut., Crass. 4.1-6.1).

Chociaż historia przekazana przez biografa z Cheronei zawiera szereg niejasności, to można na jej podstawie wyciągnąć in-

20 O nim Cornell, 2013: 489-496. 
teresujące wnioski. Zacznijmy jednak od niejasności - pierwsza jest drobna. Plutarch myli się prawdopodobnie, pisząc, że młody Krassus był z ojcem w Hiszpanii, gdy ten sprawował tam preturę (czy może raczej propreturę). Publiusz Licyniusz Krassus owszem, sprawował namiestnictwo w Hiszpanii Dalszej, ale w latach 9693, zaraz po konsulacie piastowanym w Rzymie w 97 roku (Broughton, 1952: 6). Wiadomo, że w trakcie namiestnictwa odniósł znaczące zwycięstwa nad Luzytanami i za nie został nagrodzony triumfem, który celebrował 12 czerwca 93 roku ${ }^{21}$. Prawdopodobnie właśnie w latach 96-93 szlify wojenne zbierał u jego boku młody Krassus, wchodząc, być może, jako contubernalis w skład sztabu ojca (Adcock, 1966: 1; Marshall, 1976: 10; Ward, 1977: 51); wtedy również zapewne zawiązał w Hiszpanii przyjaźnie, które tak bardzo przydały mu się po $87 \mathrm{roku}^{22}$.

Druga niejasność jest natury chronologicznej. Wiadomo, że represje na sullańczykach (i wrogach Mariusza) w Rzymie rozpoczęły się natychmiast po zwycięstwie Cynny w 87 roku. W trakcie krwawej rozprawy śmierć ponieśli między innymi ojciec i starszy brat Marka ${ }^{23}$. Nie jest pewne, czy zapłacili za przyłączenie się do konsula Oktawiusza, czy - jak wielu innych jego dawnych sojuszników - padli ofiarą zemsty Mariusza. Faktem jest natomiast, że Marka Krassusa oszczędzono. Zdaniem Plutarcha z powodu młodego wieku (mimo że urodzony około 115 roku

21 Prokonsulem w Hiszpanii Bliższej był wówczas Tytus Dydiusz. Publiusz Licyniusz Krassus i Tytus Dydiusz to jedyni poświadczeni dla lat 132-81 wodzowie obdarzeni osobnym imperium dla każdej z prowincji hiszpańskich. Obydwaj otrzymali prawo do odbycia triumfu, Dydiusz ex Hispania de Celtibereis i Krassus ex Hispania de Lusitaneis. Zob. Ascon., Pis. 19C/19 St.; Schol. Bob., ad Sest. 48, 131 St.; Plut., Crass. 1.1, a także Broughton, 1952: 7, 15; Corey Brennan, 2000: 500.

22 Por. Badian, 1958: 309-310; Marshall, 1976: 10.

23 Por. App., BC 1.72.332-333; Liv., Per. 80; Flor. 2.9.14; Cic., Sest. 48; De Or. 3.8; Tusc. 5.55; Scaur. 2.1 oraz Ascon., Scol. Bob. 131 St.; Luc. 2.124. Szerzej: Garzetti, 1941: 13; Bulst, 1964: 316-317; Lovano, 2002: 48 . 
Krassus miał wówczas już mniej więcej 28 lat!24), zdaniem współczesnych badaczy zaś raczej z powodu niewielkiego znaczenia na rzymskiej scenie politycznej ${ }^{25}$. Wkrótce jednak Marek uciekł z Rzymu i stało się to prawdopodobnie w tym samym jeszcze roku, w którym zginęli jego ojciec i brat (czyli w 87 lub najpóźniej na początku 86), gdyż Cyceron wyraźnie poświadcza, że przez niemal trzy lata Krassusa w Rzymie nie było (Cic., Brut. 308; Marshall, 1976: 12.). W Hiszpanii jednak Marek - zdaniem Plutarcha - ukrywał się tylko osiem miesięcy (Plut., Crass. 6.1). Niektórzy badacze ograniczają zatem pobyt Krassusa w Hiszpanii do ośmiu miesięcy, twierdząc że Krassus nie udał się tam od razu, lecz że wcześniej ukrywał się gdzieś na terenie Italii i dopiero w 85 roku przedostał się na Półwysep Iberyjski (Keaveney, 1984: 117). Jeśli jednak młody Krassus uciekał z Italii w obawie o własne życie, to znacznie bardziej przekonujące jest, że wyjechał od razu, wtedy bowiem represje w Rzymie były najsilniejsze. Po śmierci Mariusza, która nastąpiła 13 stycznia 86 roku (Cic., ND 3.81, Rosc. Amer. 33; Liv. Per. 80), prześladowania polityczne wyraźnie osłabły, jeśli więc Krassus przebywał w tym czasie w Italii, to zdawać by się mogło, że powinien poczuć się bezpieczniej, a nie wówczas szukać rozpaczliwie drogi ucieczki na zachód. Atmosfera, jaką - zgodnie z relacją Plutarcha - Krassus zastał w Hiszpanii, również zdaje się sprzyjać hipotezie, że przybył tam wcześniej. Wszak - co biograf wyraźnie podkreśla 26 - wszyscy wówczas w Hiszpanii bali się Mariusza! Domyślać się można, że bali się żywego Mariusza, a zatem w momencie przyjazdu Krassusa do Hiszpanii Mariusz wciąż musiał żyć. Wszystko to zdaje się świadczyć, że Krassus

24 Por. Plut., Crass. 17.3. Gelzer, 1926: 295.

25 Ward (1977: 54) podkreśla, że Krassus w momencie „masakry mariańskiej” prawdopodobnie nie osiągnął jeszcze nawet najniższego urzędu w państwie, przez co z politycznego punktu widzenia nie zagrażał cynnańczykom.

26 Plut., Crass. 4: „[Znajomych swych] zastał w największym przestrachu i drżeniu przed srogością Mariusza, jakby ten już na nich nastawał". 
przebywał w Hiszpanii dłużej niż wspomniane osiem miesięcy, a Plutarch - jak to mu się zdarza robić - skumulował wypadki (albo bezrefleksyjnie przejął liczbę ośmiu miesięcy od Fenestelli i odniósł ją do całego okresu pobytu Krassusa w Hiszpanii). Najbardziej prawdopodobna hipoteza jest zatem taka, że młody Krassus przybył do Hiszpanii już w 87 roku i rzeczywiście przez pierwszych osiem miesięcy swego pobytu w prowincji pozostawał w ukryciu. Kiedy jednak na Półwysep dotarła wieść o śmierci Mariusza (a nie Cynny - jak chce Plutarch ${ }^{27}$ ), wyszedł z ukrycia, pozostał jednak wciąż w Hiszpanii. Dopiero po otrzymaniu wiadomości o śmierci Cynny przystąpił do zbierania wojska i łupienia okolicznych, zapewne sprzyjających mariańczykom, miast.

Interesująca jest informacja o sojuszniku Krassusa, wspomnianym już Wibiuszu Pakcjanusie (Vibius Pacciaecus) ${ }^{28}$. Nazwisko wskazuje, że był osiadłym w Hiszpanii Italikiem, wchodzącym w skład grupy tak zwanych Hispanienses (Gabba, 1976: 243, przyp. 279; Syme, 1991: 467). Dorobił się tam dużego majątku. Prawdopodobnie już wcześniej pozostawał w relacjach klienckich z gens Licinia, choć jego ostrożna postawa wobec przybyłego do Hiszpanii Marka Krassusa pokazuje, że nie chciał otwarcie narażać się tamtejszym sympatykom mariańczyków. Po śmierci Cynny Pakcjanus zdecydował się jednak aktywniej pomóc młodemu zbiegowi, można bowiem z dużą dozą pewności stwierdzić, że to on stał za zebraniem owej dwuipółtysięcznej armii Krassusa, który nie miał wówczas na to ani środków - Plutarch twierdzi, że pieniądze mu się skończyły (Plut., Crass. 4) - ani wystarczających wpływów w Hiszpanii. Można nawet domniemywać, że Pakcjanus chciał na udzieleniu pomocy Krassusowi ugrać także coś dla siebie; być może wyruszył u jego boku do Sulli, który z ko-

27 Por. Plut., Crass. 6.1.

28 Jego nazwisko w manuskryptach zachowało się w różnej formie. Zob. Münzer, 1942: 2062; Syme, 1991: 467; Weinrib, 1990: 22; Konrad, 1994: 112. 
lei za okazaną Krassusowi pomoc z pewnością go nagrodził29. Dodajmy, że związki Pacciaeci z Krassusem przetrwały do czasów późniejszych, a prawdopodobnie syn wspominanego wyżej Pakcjanusa walczył u boku Krassusa w bitwie pod Karrami (Plut., Crass. 32) ${ }^{30}$.

O ile informacja, że Krassus przy pomocy swego sojusznika Pakcjanusa zebrał wspomnianą małą armię, jest wysoce prawdopodobna, to można już zastanawiać się nad wiarygodnością relacji Plutarcha dotyczącej akcji podjętej przez młodego wodza przeciwko miastom prowincji, a zwłaszcza złupienia Malaki. Podobno sam Krassus zaprzeczał później tym doniesieniom, co oznacza, że plotki na ten temat krążyły już za jego życia i wcale nie można wykluczyć, że nie były wynikiem propagandy rozsiewanej przez licznych wrogów, których Krassus niewątpliwie miał w Rzymie. O ile bowiem prawdopodobne jest, że rzeczywiście podjął on w Hiszpanii jakąś akcję przeciwko sojusznikom mariańczyków, o tyle wydaje się, że akurat ta część Hiszpanii, w której wówczas przebywał i gdzie najpewniej - dzięki pomocy Pakcjanusa - udało mu się zwerbować żołnierzy, po śmierci Cynny przeszła na stronę sullańczyków i podczas wojny sertoriańskiej pozostała im wierna (Ward, 1977: 60-61). Trudno sobie także wyobrazić, by nowi żołnierze Krassusa, zwerbowani na tamtych terenach, łupili ziemie i miasta pobratymców. Wydaje się zatem, że informacja o łupieskiej akcji Krassusa w Hiszpanii była wynikiem raczej pomówień wrogów niż rzeczywistym zdarzeniem (Garzetti, 1941: 5). Także wzmianka o rzekomym ataku na Malakę, największy wówczas port południowej Hiszpanii (Schulten, 1928: 823-824), zapewniający komunikację między Hiszpanią Dalszą i Afryką, brzmi podejrzanie. To stamtąd Krassus musiał pozyskać okręty,

29 Według Wisemana (1971: 248), Pakcjanus wszedł do nowego sullańskiego senatu. Jeśli rzeczywiście tak było, to możliwe, że na początku 81 roku w randze legata towarzyszył w drodze do Hiszpanii Gajuszowi Anniuszowi, sullańskiemu namiestnikowi obydwóch tamtejszych prowincji.

30 Por. Gabba, 1976: 111; Syme, 2016: 124. 
jeśli chciał przedostać się do Metellusa, więc zamiast atakować port, o wiele logiczniej byłoby dogadać się z tamtejszymi władzami w tej sprawie, zwłaszcza że i tam przeważały w późniejszym okresie sympatie prosullańskie (Gabba, 1954: 309-310; 1976: 111; Ward, 1977: 61). Po zdobyciu okrętów Krassus opuścił Hiszpanię i udał się do przebywającego w Afryce Metellusa. Jak już wzmiankowałem, między obydwoma wodzami doszło jednak do sporu i choć Plutarch nie podaje szczegółów, można podejrzewać, że miało to podłoże osobiste (Plut., Crass. 6.2). Metellus znany ze swej arystokratycznej wyniosłości ${ }^{31}$, zapewne potraktował Krassusa w sposób, który uwłaczał młodemu, opromienionemu niedawnymi sukcesami wodzowi. Możliwe także, że Metellus nie był jeszcze do końca przekonany, by poprzeć Sullę, a wątpliwości w tej sprawie nie miał już Krassus, nieporozumienia zatem dotyczyć mogły także kwestii pomocy dla Sulli w zbliżającej się wojnie z cynnańczykami. Jakkolwiek było, obrażony Krassus opuścił Afrykę i pożeglował wspierać powracającego ze Wschodu prokonsula (Plut., Crass. 6.2. Marshall, 1976: 13).

Akcja Krassusa, czyli zebranie w krótkim czasie niemałej siły zbrojnej, pokazała, że mariańskie wpływy w prowincjach hiszpańskich po śmierci Mariusza i Cynny wyraźnie osłabły. Śmierć liderów mariańskich była wszakże tylko jedną z przyczyn takiego stanu rzeczy. Po zwycięstwie nad Mitrydatesem wyraźnie bowiem wzrosła pozycja Sulli w Republice. Również dotychczasowy namiestnik prowincji hiszpańskich, Gajusz Waleriusz Flakkus, wykazywał zadziwiającą bezczynność wobec działań młodego Krassusa (Badian, 1962: 59; Ward, 1977: 61). Być może pojawiły się nawet wątpliwości co do jego wierności sprawie mariańskiej, zwłaszcza że factio Flakkusów w Rzymie, na czele której stał brat namiestnika prowincji hiszpańskich Lucjusz, dążyła do kompromisu z Sullą i dystansowała się od działań skrajnego skrzydła mariańczyków (Ładoń, 2013a: 94-95). Aby zabezpieczyć kontrolę nad prowincjami hiszpańskimi, mariańczycy musieli dokonać zmiany na stanowisku ich namiestnika. Flakkusowi pozostawio-

31 Por. np. Lovano, 2002: 40. 
no jedynie zarząd Galii Zaalpejskiej (Badian, 1964: 89; Broughton, 1986: 211). Miało to wywołać wrażenie, że nie utracił on zaufania rządu w Rzymie, a tylko uwalniano go od części obowiązków. Jednocześnie skutecznie neutralizowano jednak siły Flakkusa, które, zamknięte w kleszczach między Italią a Hiszpanią, stawały się mniejszym zagrożeniem w razie jego ewentualnego przejścia na stronę Sulli (Konrad, 1994: 86).

Nowym namiestnikiem (prawdopodobnie obydwóch) prowincji hiszpańskich ${ }^{32}$ został Kwintus Sertoriusz, jeden z przywódców mariańczyków, doskonały wódz, który służył już w Hiszpanii Bliższej w latach 97-93 jako trybun wojskowy pod wodzą Tytusa Dydiusza ${ }^{33}$. Desygnowanie tego niezwykle zdolnego mariańczyków na wspomniane stanowisko to kwestia złożona, którą omówiłem już w innym miejscu (Ładoń, 2011: 40-44) ${ }^{34}$. $\mathrm{Z}$ punktu widzenia tematu niniejszego artykułu ważne jest zadanie, jakie Sertoriuszowi powierzono, czyli stworzenie azylu dla mariańczyków na wypadek ich klęski w wojnie z Sullą (Plut., Sert. 6.2) $)^{35}$.

Sertoriusz prawdopodobnie otrzymał instrukcje, aby nie prowokować żadnych konfliktów z miejscowymi i - o ile było to możliwe - unikać z nimi walki. Dodatkowo miał złagodzić politykę względem ludności zamieszkujące prowincję. Nawiązał także kontakty z wodzami miejscowych plemion, chcąc zyskać ich przychylność (Plut., Sert. 6.4) ${ }^{36}$. Oprócz tego zmienił status niektórych miast hiszpańskich, wprowadził w nich wewnętrzną autonomię, zniósł część podatków na rzecz Rzymu, a także uciążliwy dla mieszkańców prowincji obowiązek przyjmowania

32 Plut., Sert. 6.1-3; App., BC 1. 392, Ib. 101. Badian, 1962: 96, 104, przyp. 164-165.

33 Sall., Hist. 1.88 M - Gell. 2.27.2; Plin. NH 22.12; Plut., Sert. 3.3.

García Morá, 1991: 149 i n.

34 Por. Konrad, 1994: 87.

35 Por. Iul. Exuper. 8. W latach osiemdziesiątych Hiszpania rzeczywiście stała się miejscem schronienia dla wielu uciekinierów z Rzymu. Zob. Gran. Lic 35.7 Cr.

36 Por. Sall., Hist. $94 \mathrm{M}=83 \mathrm{McG}$. 
rzymskich legionistów na kwatery zimowe ${ }^{37}$. Wszystkie te posunięcia miały zapewnić popularność w Hiszpanii nie tyle Sertoriuszowi, ile reprezentowanej przez niego sile politycznej, czyli mariańczykom.

Tymczasem zwycięstwo Sulli całkowicie zmieniło sytuację nie tylko w Republice, lecz także w prowincjach hiszpańskich. Dzięki błyskawicznej kampanii przeprowadzonej przez sullańskiego namiestnika, Gajusza Anniusza, Sertoriusz wraz z podległymi mu żołnierzami został wypędzony z Hiszpanii (Plut., Sert. 7) ${ }^{38}$. Schronił się w Mauretanii, gdzie wmieszał się w konflikt dynastyczny (Plut., Sert, 9. Konrad, 1994: 110-115). Przeciwko Sertoriuszowi Sulla wyekspediował Pakcjanusa, prawdopodobnie wspomnianego już wcześniej przyjaciela Krassusa (Plut., Sert. 9.3) ${ }^{39}$. Jeśli wyjechał z Hiszpanii z Krassusem, mógł teraz powrócić na Półwysep Iberyjski w randze legata u boku Anniusza i otrzymać misję pozbycia się Sertoriusza. Ten ostatni łatwo rozbił jednak Pakcjanusa, który poległ w bitwie, zaś resztki jego armii wcielił do własnych szeregów.

Mniej więcej w tym samym czasie, gdy Gajusz Anniusz wypędzał Sertoriusza z Hiszpanii, w Rzymie szalały sullańskie proskrypcje ${ }^{40}$. Setki prawdziwych i domniemanych wrogów Sulli zostało zabitych, reszta uciekała $z$ Italii. Hiszpanię - z uwagi na popularność mariańczyków na tamtym terenie niewątpliwie często wybierała jako miejsce schronienia opozy-

37 Plutarch (Sert. 6,4) nie precyzuje co prawda tych zmian, możemy się jednak domyślać, że znalazły one swoje odzwierciedlenie w wydanej później lex Antonia de Termessibus. Por. Abbott, Johnson, 1968: 42-45; 279-282; Richardson, 1986: 169.

38 Zob. Antela-Bernández, 2012: 37-47; Ładoń, 2013b: 29-38.

39 Zob. przyp. 30.

40 Ustawa o proskrypcjach wydana została już w 82 roku (Rotondi, 1962: 349); największy zasięg osiągnęły one w pierwszej połowie roku 81. Oficjalnie proskrypcje zostały zakończone 1 czerwca tego roku (Cic., Rosc. Amer. 128), nie doprowadziło to jednak do zahamowania prześladowań względem ocalałych do tej pory popularów. Zob. Broughton, 1952: 69 i 73-74, przyp. 6. O proskrypcjach sullańskich zob.: Lanzani, 1936: 5-25 i zwłaszcza 93-121; Keaveney, 1982: 148-168; Hinard, 1985: 17-223. 
cja antysullańska, a skala exodusu z Italii na Półwysep Iberyjski była zapewne o wiele większa, niż zostało to odnotowane w źródłach (Gran. Lic. 35.7). Wśród uciekinierów znalazło się zapewne wielu Italików, w tym Samnitów, którzy w wojnie domowej poparli cynnańczyków i wobec których Sulla prowadził represje (Strab. 5.249) ${ }^{41}$.

Jako że - jak wspominałem - Sertoriusza w Hiszpanii Dalszej i Bliższej zastąpili namiestnicy sullańscy ${ }^{42}$, uciekinierzy z Italii chronili się prawdopodobnie w miejscach, gdzie nie sięgała ich władza. Niewątpliwie spora ich część przedostała się do Luzytanii. To właśnie tam zrodził się pomysł wezwania Sertoriusza z powrotem do Hiszpanii po to, aby stanął na czele antysullańskiej rewolty (Plut., Sert. 7.1; Konrad, 1994: 115-116). Ideę tę wzmacniały także agresywne rządy sullańskich namiestników, którzy po wypędzeniu Sertoriusza odeszli od jego łagodnej polityki wobec miejscowych i powrócili do restrykcyjnych przepisów, które miały na celu ściągnięcie do Italii jak najwięcej pieniędzy i uzupełnienie pustego na skutek wojny skarbca rzymskiego (Spann, 1987: 60). Za wezwaniem Sertoriusza do Hiszpanii stali więc nie tyle (albo nie tylko) Luzytanie, ale także zaniepokojeni Hispanienses i mariańczycy - ci, którzy licznie przybyli do Hiszpanii, aby schronić się tak przed oprawcami wysłanymi przez Sullę i ci, których być może Sertoriusz pozostawił, gdy opuszczał Hiszpanię i wyruszał do Afryki (Konrad, 1987: 524-527). W sumie u boku Sertoriusza samych tylko Rzymian i Italików (ludzi, których nazywał Rzymianami) zgromadziło się dwa tysiące sześciuset ${ }^{43}$. Nie była to siła, która mogłaby zagrozić Republice czy choćby pano-

41 Por. App., BC 1.96.446. O Italikach w obozie sertoriańskim zob. Gabba, 1976: 109-115. Por. Salmon, 1964: 60-79 i Keaveney, 1983: 501-544 o stosunku Sulli do Italików.

42 Zwycięstwo nad Sertoriuszem to ostatnia wiadomość o działalności Gajusza Anniusza. Nie wiadomo, czy wrócił do Rzymu. W 80 roku zastąpili go w Hiszpanii Dalszej Lucjusz Fufidiusz, a w Hiszpanii Bliższej Marek Domicjusz Kalwinus. Zob.: Sall., Hist. I, 111M; Plut., Sert. 12, 3. Broughton, 1986: 84, 93.

43 Dyskusja nad stanem liczebnym wojsk Sertoriusza: Scardigli, 1970: 177-181; Brunt, 1971: 470; Cadiou, 2008: 120. 
waniu sullańczyków w Hiszpanii, niemniej była wystarczająca, aby utrudnić zarząd prowincji i wzbudzić zaniepokojenie władz w Rzymie.

Niektórzy, zwłaszcza dawniejsi, badacze utrzymywali, że Sertoriusz przyjął zaproszenie Luzytanów do przewodzenia im w walce o zrzucenie jarzma rzymskiego i oskarżyli go o zdradę państwa, nie bacząc na to, że nie czynili tego nawet starożytni (Berve, 1929: 199-227; Wickert, 1954: 97-106). Obecnie tego poglądu się już w nauce nie akceptuje (Spann, 1987: 58-62; Konrad, 1987: 525; 1994: 116). Bardziej prawdopodobne, że między Sertoriuszem, popierającymi go Rzymianami i Italikami (Hispanienses) z jednej strony a ludnością tubylczą (Luzytanami) z drugiej doszło do niepisanej umowy: Luzytanie zgodzili się uznawać Sertoriusza za legalnego prokonsula, przedstawiciela mariańczyków i jako auxilia udzielili mu pomocy w walce z sullańczykami, prawdopodobnie zaś w zamian Sertoriusz zobowiązywał się prowadzić w prowincjach hiszpańskich taką samą politykę, jaką zapoczątkował w okresie swojego namiestnictwa (Spann, 1987: 170).

Po powrocie Sertoriusza na Półwysep Iberyjski i kilku sukcesach, jakie odniósł on w walce z namiestnikami sullańskimi, do Hiszpanii jeszcze szerszym strumieniem zaczęli napływać uciekinierzy z Italii, nie tylko po to, aby się tam schronić przed represjami w Rzymie, lecz także, aby walczyć z uzurpatorami - tak bowiem postrzegali sullańczyków - dzierżącymi aktualnie władzę w państwie. Najwięcej opozycjonistów, w tym wielu byłych rzymskich senatorów, przedostało się na Półwysep Iberyjski po upadku buntu Marka Emiliusza Lepidusa w 77 roku, a przywiódł ich były pretor, Marek Perperna ${ }^{44}$. Hiszpania stała się więc w latach siedemdziesiątych I wieku nie tylko (czy też może nie tyle) miejscem schronienia dla opozycji politycznej - przekształciła

44 Plut., Sert. 15.1; App., BC 1.107-108; Iul. Exuper. 7; Oros. 5.23.12; 5.24.16. Najprawdopodobniej Perperna był legatem Lepidusa. Zob.: App., BC 1.108; Iul. Exuper. 7; Broughton, 1952: 91. Por. Bartsch, 1908: 61; Badian, 1958: 270, przyp. 3. Szerzej o Perpernie zob.: Münzer, 1937: 897-901. 
się w bazę mariańczyków, swoisty ośrodek rzymskiej władzy na uchodźstwie z emigracyjnym senatem i urzędnikami ${ }^{45}$. Dopiero koniec tak zwanej wojny sertoriańskiej, będący jednocześnie - w szerszym kontekście - końcem pierwszej wojny domowej, pozwolił na powrót uchodźców do Rzymu. Nie wszyscy z amnestii skorzystali - część pozostała na Półwyspie Iberyjskim, z jednej strony coraz ściślej wiążąc Hiszpanię z Imperium Rzymskim, a z drugiej tworząc klientelę nowego gracza na rzymskiej scenie politycznej - Gnejusza Pompejusza ${ }^{46}$.

\section{Bibliografia}

Abbott, F. F., Johnson, A. C. (1968): Municipal Administration in the Roman Empire. New York: Russell and Russel.

Adcock, F. E. (1966): Marcus Crassus, millionaire. Cambridge: W. Heffer and Sons.

Amela Valverde, L. (2002): Las clientelas de Cneo Pompeyo Magno en Hispania. Barcelona: Universitat de Barcelona.

Appel, H. (2013): Kontrowersje wokót „senatus consultum ultimum”. Studium z dziejów późnej republiki rzymskiej. Toruń: Wydawnictwo Naukowe Uniwersytetu Mikołaja Kopernika.

Badian, E. (1958): Foreign Clientelae (264-70 BC). Oxford: Clarendon Press.

Badian, E. (1962): “Waiting for Sulla”. Journal of Roman Studies 52: 47-61.

Badian, E. (1964): Studies in Greek and Roman History. Oxford: Basil Blackwell.

Bartsch, B. (1908): Die Legaten der römischen Republik vom Tode Sullas bis zum Ausbruche des zweiten Bürgerkrieges. Breslau: H. Fleischmann.

45 App., BC 1.108.507-508 ; Ib., 101.439; Mith. 68.286; Plut., Sert. 22.3. Szerzej: Spann, 1987: 169-174; Konrad, 1994: 184-187; Ładoń, 2011: 65-70.

46 Zob. np. Wilson, 1966: 32: „Pompeius took a personal attitude to his defeated enemies, making it quite clear that their best hope for the future lay in becoming his clientes, and his later influence in Citerior must have been largely based on Roman survivors of Sertorius' armies who saw their future in Italy as uncertain, and preffered to stay in the land of their long exile, under his protection". O klientach Pompejusza w Hiszpanii: Amela Valverde, 2002. 
Berve, H. (1929): Sertorius. Hermes 64: 199-227.

Broughton, T. R. S. (1951-1952): The Magistrates of the Roman Republic. Vol. 1-2. New York: American Philological Association.

Broughton, T. R. S. (1986): The Magistrates of the Roman Republic. Vol. 3, Supplement. Atlanta: Scholar Press.

Brunt, P. A. (1971): Italian Manpower 225 BC-AD 14. Oxford: Oxford University Press.

Bulst, C. M. (1964): "Cinnanum Tempus: A Reassessment of the 'Dominatio Cinnae'". Historia 13: 307-337.

Cadiou, F. (2008): Hibera in terra miles. Les armées romaines et la conquête de l'Hispanie sous la république (218-45 av. J.-C.). Madrid: Bibliothèque de la Casa de Velázquez.

Carney, T. F. (1961): “The Flight and Exile of Marius”. Greece and Rome 8: 98-121.

Corey Brennan, T. (2000): The Praetorship in the Roman Republic. Vol. 1-2. Oxford: Oxford University Press.

Cornell, T. J. (ed.), (2013): The Fragments of the Roman Historians. Vol. 1. Oxford: Oxford University Press.

Gabba, E. (1954): "Le origini della guerra sociale e la vita politica romana dopo l'89 a. C.". Athenaeum 32: 41-114; 293-345.

Gabba, E. (1958): Appiani Bellorum civilium liber primus. Firenze: La Nuova Italia.

Gabba, E. (1976): Republican Rome, the Army and the Allies. Berkeley/Los Angeles: University of California Press.

Garcia Morá, F. (1991): Quinto Sertorio. Roma. Granada: Universidad de Granada.

Garzetti, A. (1941): “M. Licinio Crasso”. Athenaeum 19: 1-37.

Gelzer, M. (1926): M. Licinius Crassus Dives. W: Real-Encyclopädie der classischen Altertumswissenschaft, Bd. 13.1. Stuttgart: J.B. Metzlerscher Verlag, 295-331.

Gruen, E. S. (1974): The Last Generation of the Roman Republic. Berkeley/Los Angeles/London: University of California Press.

Heaton, J. W. (1939): Mob Violence in the Late Roman Republic 133-44 BC. Urbana: The University of Illinois Press.

Hinard, F. (1985): Les proscriptions de la Rome républicaine. Roma: Publications de l'École Française de Rome.

Keaveney, A. (1983): "Sulla and Italy". Critica Storica 19: 501-544.

Keaveney, A. (1984): “Who Were the Sullani?”. Klio 66: 114-150. 
Konrad, Ch. F. (1987): "Some Friends of Sertorius". American Journal of Philology 108: 519-527.

Konrad, Ch .F. (1989): "Cotta Off Mellaria and the Identities of Fufidius", Classical Philology 84: 119-129.

Konrad, Ch. F. (1994): Plutarch's Sertorius. A Historical Commentary. Chapel Hill/London: The University of North Carolina Press.

Kowalski, H. (1983/1984): "Przemoc jako metoda walki wyborczej w Rzymie w okresie schytku republiki (78-50 p.n.e.)". Annales Universitatis Mariae Curie-Skłodowska 38-39: 75-92.

Kowalski, H. (2007): “'Leges per vim contra auspicia latae'. Religia, polityka i prawo karne w okresie schyłku republiki”. W: A. Dębiński, H. Kowalski, M. Kuryłowicz (eds.), Salus rei publicae suprema lex. Ochrona interesów państwa w prawie karnym starożytnej Grecji i Rzymu. Lublin: Wydawnictwo KUL, 103-114.

Labitzke, M. (2009): Marius. Der verleumdete Retter Roms. Münster: AT Edition. Labruna, L. (1979): “La violence instrument de lutte politique à la fin de la République". Dialogues d'Histoire Ancienne 17: 119-137.

Lanzani, C. (1936): Lucio Cornelio Silla dittatore. Milano: U. Hoepli.

Letzner, W. (2000): Lucius Cornelius Sulla. Versuch einer Biographie. Münster: LIT.

Lintott, A. (1968): Violence in Republican Rome. Oxford: Oxford University Press.

Lovano, M. (2002): The Age of Cinna: Crucible of Late Republican Rome. Stuttgart: Steiner.

Ładoń, T. (2011): Wojna sertoriańska (80-71 przed Chr.). Oświęcim: Napoleon V. Ładoń, T. (2013a): “Sulla's Peace Negotiations with Cinna's Faction in 85-83 BC”. W: D. Słapek, I. Łuć (eds.), Lucius Cornelius Sulla. History and Tradition. Lublin: Maria Curie-Skłodowska University Press, 91-102.

Ładoń, T. (2013b): "Kariera Gajusza Anniusza w świetle źródet literackich i numizmatycznych". Wieki Stare i Nowe 5:29-38.

Marshall, B. A. (1976): Crassus. A Political Biography. Amsterdam: Hakkert.

Münzer, F. (1918): “L. Magius”. W: Real-Encyclopädie der classischen Altertumswissenschaft, Bd. 14.1. Stuttgart: J.B. Metzlerscher Verlag, 972.

Münzer, F. (1937): “M. Perperna”. W: Real-Encyclopädie der classischen Altertumswissenschaft, Bd. 19.1. Stuttgart: J.B. Metzlerscher Verlag, 897-901. Münzer, F. (1942): "Paccianus". W: Real-Encyclopädie der classischen Altertumswissenschaft, Bd. 18.2. Stuttgart: J.B. Metzlerscher Verlag, 2062. 
Ooteghem, J. van (1963): Caius Marius. Bruxelles: Palais des Académies.

Ooteghem, J.van (1967): Les Caecilii Metelli de la république. Bruxelles: Palais des Académies.

Richardson, J. S. (1986): Hispaniae. Spain and the Development of Roman Imperialism 218-82 BC. Cambridge: University Press.

Richardson, J. S. (2000): Appian Wars of the Romans in Iberia. Warminster: Aris and Phillips.

Rijkhoek, K. G. (1992): Studien zu Sertorius 123-83 v. Chr. Bonn: Dr. Rudolf Habelt.

Rotondi, G. (1962): Leges publicae populi romani. Hildesheim: G. Olms.

Rouland, R. (1979): “La violence politique au temps de Cicéron”. L'Histoire 10:32-41.

Salmon, E. T. (1964): "Sulla Redux". Athenaeum 42: 60-79.

Scardigli, B. (1970): "A proposito di due passi su Sertorio". Atene e Roma 15: 174-181.

Schuller, W. (1974/1975): “Die Rolle der Gewalt im politischen Denken der späten römischen Republik". Index 5: 140-154.

Schulten, A. (1928): "Malaca”. W: Real-Encyclopädie der classischen Altertumswissenschaft, Bd. 27. Stuttgart: J.B. Metzlerscher Verlag, 823-824.

Schulten, A. (ed.) (1937): Fontes Hispaniae Aantiquae, Vol. IV. Barcelona: Liberia Bosch.

Sherwin-White, A. N. (1956): "Violence in Roman Politics". Journal of Roman Studies 46: 1-9.

Smith, R. E. (1977): "The Use of Force in Passing Legislation in the Late Republic", Athenaeum 55: 150-174.

Spann, P. O. (1987): Quintus Sertorius and the Legacy of Sulla. Fayetteville: University of Arkansas Press.

Syme, R. (1991): Roman Papers, Vol. VI, ed. A. R. Birley. Oxford: Clarendon Press.

Syme, R. (2016): Approaching the Roman Revolution. Papers on Republican History, ed. F. Santangelo. Oxford: University Press.

Ward, A. M. (1977): Marcus Crassus and the Late Roman Republic. London/ Columbia: University of Missouri Press.

Weinrib, E. J. (1990): The Spaniards in Rome: from Marius to Domitian. New York: Routledge.

Wickert, L. (1954): "Sertorius“. W: H. Seehase (ed.), Rastloses Schaffen: Festschrift für Friedrich Lammert. Stuttgart: Kohlhammer, 97-106. 
Wilson, A. J. N. (1966): Emigration from Italy in the Republican Age of Rome. New York: Barnes and Noble.

Wiseman, T. P. (1971): New Men in the Roman Senate 139 BC - AD 14, London: Oxford University Press. 